\title{
The Role of Leadership Style in Organizational Culture and Competence to Improve Village Fund Management Accountability
}

Moh. Ubaidillah ${ }^{*}$,

Mahesti Cahayuni'2,

1,2 Department of Accounting, Fakulty of Economic and Business, Universitas PGRI Madiun, Madiun, Indonesia

\begin{tabular}{ll}
\hline ARTICLE INFO & ABSTRACT \\
\hline ISSN: 2723-1097 & $\begin{array}{l}\text { This research aims to find out and obtain empirical evidence about the } \\
\text { influence of organizational culture and competence on the accountability of } \\
\text { village fund management with leadership style as a moderation variable. }\end{array}$ \\
Keywords: & $\begin{array}{l}\text { The sampling in this study used purposive sampling method that produced } \\
\text { a sample of 90 village treasurers from 18 districts of Magetan district. This }\end{array}$ \\
Accountability, & $\begin{array}{l}\text { research data analysis method uses Structural Equation Modeling (SEM) } \\
\text { Competence, } \\
\text { Orralysizational with Partial Least Squares (PLS). The results showed that the } \\
\text { Culture, Pint Style } \\
\text { competence and culture of the organization had a positive effect on the } \\
\text { accountability of village fund management. Leadership style is able to } \\
\text { moderate the influence of organizational culture and competence on the } \\
\text { accountability of village fund management positively and significantly. }\end{array}$ \\
\hline
\end{tabular}

\section{Introduction}

Since the enactment of Law No. 6 of 2014 on Villages, the village is authorized by the central government to organize and develop its own area. Large budget allocation policies have consequences for their management that should be implemented professionally, effectively, efficiently, and accountable. Considering that the funds received by the village are quite large and increasing every year, it is necessary to manage an accountable village fund because there is a lot of corruption year on year is increasing.

Based on Indonesia Corruption Watch (ICW) data, village funds corruption continues to increase from year to year. ICW records, corruption of village funds in 2015 reached 22 cases. The number of cases rose to 48 in 2016 and rose again to 98 and 96 in 2017 and 2018 (Novellno, 2019). During 2019 there were 46 cases of corruption in the village budget sector out of 271 corruption cases. Corruption of the village budget is recorded to give the state losses up to RP 32.3 billion (Ramadan, 2020).

One example of the case of corruption of village funds by the village head Sempol, Maospati subdistrict, Magetan regency, East Java. The perpetrator admitted that embezzling village funds for three years amounted to RP 300 million and perverting the village's cash budget of more than Rp 100 million. The perpetrator was

Journal of Business and Management Review Vol. 3 No. 12022 Page 082-093

DOI: $10.47153 /$ jbmr31.3012022

*Corresponding Author

Email address: mohubaidillah@unipma.ac.id 
sentenced to 2 years and 6 months by the Surabaya East Java corruption criminal court (Sukoco, 2019).

There is a case of corruption of village funds because the management is not accountable because the village government apparatus is less competent and not supported by a good village organizational culture. In addition, the leadership style of the village head becomes the main factor that affects the accountability of village fund management, because an organization will run smoothly in achieving the organizational goals that have been set greatly influenced by leadership factors. Therefore, the village head has always been the focus of evaluation as an assessment of the success of accountable village fund management.

Previous research related to competency variables conducted by Mada, Kalangi and Ganaliel (2017) resulted from his research that the competence of village fund management apparatus, the commitment of village government organizations and community participation positively affect the accountability of village fund management in Gorontalo district. Umaira and Adnan (2019) the results of their research that community participation, human resource competence and supervision have a positive influence on the management of village funds. The results of the research of Pahlawan, Wijayanti and Suhendro (2020) showed that the competence of the village apparatus and community participation had a positive and significant effect while the internal control system and utilization of information technology were insignificant to the accountability of village fund management.

Previous research related to organizational culture conducted by Widiyanta, Herawati and Atmadja (2017) resulted from his research that the competence of the apparatus, organizational culture, whistleblowing and internal control systems had a positive and partially significant impact on fraud prevention in village fund management. Reni and Syamsir (2019) the results of their research that organizational culture has a positive influence on financial management performance.

This research focuses on accountability for village fund management because there is a lot of corruption year after year after the enactment of Law No. 6 of 2014 on Villages. This research sample was conducted in Magetan regency, because one of the villages occurred corruption. Researchers choose leadership style variables because researchers have not found limited studies that use these variables in accountability for village fund management. Researchers found leadership style variables as moderation variables in managerial performance performed by Amertadewi and Dwirandra (2013). Organizational culture variables are not widely used. While the competency variable has been widely used research before. The difference with previous research and the newness of this study is that the leadership style variable has not been examined and made the moderation variable as a moderation variable between organizational culture and competence with accountability of village fund 
management. Therefore, this study aims to find out the influence of organizational culture and competence on accountability of village fund management with leadership style as a moderation variable.

\section{Literature Review}

\section{Accountability of Village Fund Management}

According to Mardiasmo (2009) explained that the understanding of public accountability as the obligation of the trust holder (agent) to provide accountability, present, report, and disclose all activities and activities that are their responsibility to the principal who has the right to hold it accountable. Public accountability consists of two types, namely: 1) accountability for the management of funds to higher authorities (vertical accountability), and 2) accountability to the wider community (horizontal accountability).

People in this democratic era always demand a clean, responsible, and transparent government accountability for the increasingly high accountability of government financial management (Hupe and Hill, 2007). Accountability refers to the mechanisms given to public officials to be able to explain and ensure that they have acted properly, behaved ethically and responsibly for their performance (Scott, 2002).

\section{Competence}

According to Sudarmanto (2009) define competence as knowledge of an individual's expertise, abilities, or personal characteristics that directly affect job performance. Competence describes the basic knowledge and performance standards required to successfully complete a job or hold a position. Ainsworth, Smith and Millership (2007) say that competence is a combination of knowledge and skills relevant to labor. Competence is the capacity to perform a job or task based on a set standard.

\section{Organizational Culture}

According to Robbins (2001), organizational culture refers to a system of shared meaning embraced by members that distinguishes it from other organizations. David (2004) states that organizational culture is a pattern of behavior developed by an organization that it learns when experiencing problems of external adaptation and internal integration, which has proven to be good enough to be endorsed and taught to new members as a way to be aware, think and feel.

Organizational culture in the public sector emphasizes public service because it is influential in creating good public services. One of the organizational cultures is the personal competence of employees. Services provided to the public is a form of output 
that has been processed by employees and workers in the organization. With the interaction or communication between employees and communication interaction between employees and the public, it will foster a good organizational culture. Good service is no longer an obligation but has become a habit or culture.

\section{Leadership Style}

Leadership is the backbone of organizational development because without good leadership it will be difficult to achieve organizational goals. If a leader is trying to influence the behavior of others, then that person needs to think about his or her leadership style. Leadership style is how a leader performs his or her leadership functions and how he is seen by those who seek to lead him or those who may be observing from the outside (Robert, 1992). James et. (1996) says that leadership styles are various patterns of behavior favored by leaders in the process of directing and influencing workers. Leadership style is behavior and strategy, as a result of a combination of philosophy, skill, trait, attitude, which a leader often applies when he tries to influence the performance of his subordinates (Tampubolon, 2007).

\section{Research Hypothesis}

Individual competencies such as management skills in all organizations are an absolute must-have factor for the apparatus. Individual competence is also shaped by expertise, i.e. things that are intellectual and physical. The low competence of human resources of the village apparatus becomes an obstacle in the process of managing the allocation of village funds (Thomas, 2013). Research Raharjo et al. (2013) showed that human resource capability factors affect the performance of village government officials. Alimbudiono and Fidelis (2004), Sudiarianti (2013) showed that $\mathrm{hr}$ competence affects the quality of financial statements and the quality of financial statements has an influence on financial accountability (Fitriyah, 2013). Santoso (2016) found that human resource competence has a positive effect on regional financial accountability. Based on the study of compliance theory and existing research, the following hypotheses.

\section{H1: Competence affects the accountability of village fund management}

Organizational culture is the norms, values, assumptions, beliefs, habits made in an organization and approved by all members of the organization as guidelines or references in the organization in carrying out its activities both for employees and for the benefit of others. The results Baba (2018) that organizational culture will create a background related to the environment, ways of work, attitudes, behaviors, and views of employees towards the organization they are in. If the culture of the village government organization is good then all government apparatus is also good and will 
have an impact on the good management of village funds as well and accountable. The hypothesis of this study is as follows.

$\mathrm{H} 2$ : Organizational culture affects the accountability of village fund management.

Competence is the knowledge of an individual's personal expertise, abilities, or characteristics that directly influence job performance. Competence describes the basic knowledge and performance standards required to successfully complete a job or hold a position. The village government needs to improve the competence of the village government apparatus to achieve accountable management of village funds. To improve the competence of the village apparatus needs support from the leader or village head by providing training and continuing studies. According to Kartono (2005) leadership is the ability to give constructive influence to others to make a cooperative effort to achieve the goals that have been planned. The research hypothesis is as follows.

H3: competence affects the accountability of village fund management with leadership style as a moderation variable.

Organizational culture is the norms, values, assumptions, beliefs, habits made in an organization and approved by all members of the organization as guidelines or references in the organization in carrying out its activities well. If the culture of the village government organization is good in accordance with the central government regulations will support the creation of accountable management of village funds. To create a good village government organizational culture there needs to be support from the leader or village head. Because the village chief has a huge influence in decision making. According to Robbins (2006) leadership is a process of influencing group activities that are organized to achieve common goals. Therefore, this study hypothesizes the following.

H4: organizational culture influences accountability of village fund management with leadership style as a moderation variable.

\section{Research Model}

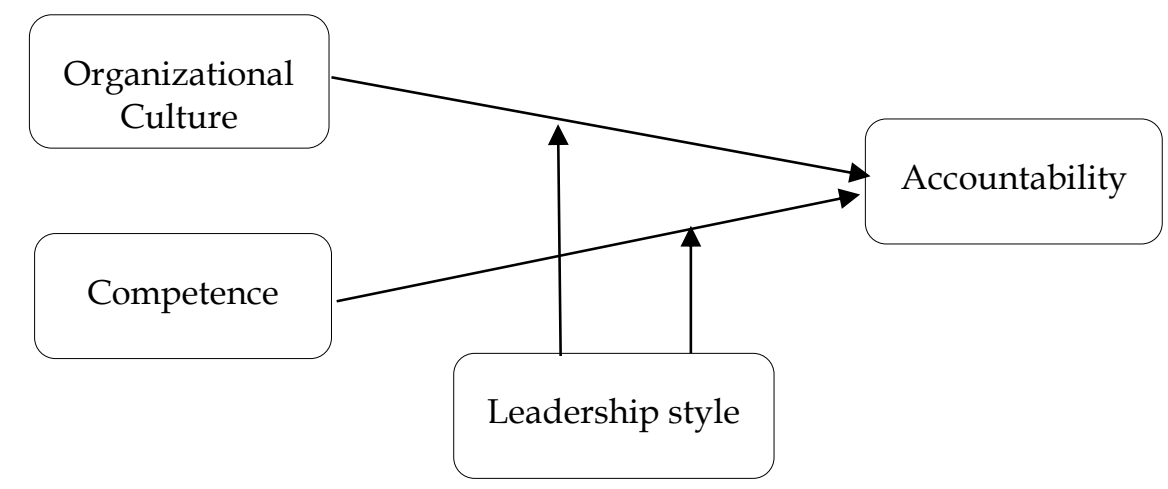




\section{Method}

This research is quantitative research with primary data. The primary data in question is information obtained from first hand by disseminating questionnaires to respondents. This research sample is the village treasurer in Magetan regency. Sampling technique is done by purposive sampling method with criteria, namely: 1) each sub-district is taken by seven villages. 2) Sampling of five villages from subdistricts based on the largest funds managed by the village.

Measurement of variables in the study used a likert scale with one to five assessment numbers. Measurement of village fund management accountability variables using indicators in Ubaidillah and Arumsari research (2019) namely the formulation of financial plans, implementation and approval of activities, evaluating financial work, and the implementation of financial reporting. Competency variables are measured using indicators in Umaira and Adnan research (2019) namely work experience, educational background, having expertise / knowledge and skills. Measurement of leadership style variables using indicators presented by Trang (2013) namely goal setting, decision making, communication, interaction, motivation, and control. Organizational Culture Variables are measured by indicators presented by Rivai and Mulyadi (2013) namely innovation and risk-taking, aggressiveness, outcome orientation, person orientation, team orientation, detailed attention, stability.

This research data analysis technique uses Partial Least Square (PLS) because the study uses latent variables or many indicators in each variable. PLS is a structural equation modeling (SEM) model based on components or variants. The study used PLS because it is multivariate and all latent variables. According to Ghozali (2006), the goal of PLS is to help researchers for predictive purposes. Its formal model defines latent variables as linear aggregates of their indicators. Weight estimates to create latent variable score components are obtained based on how the inner model (the structural model that connects between latent variables) and the outer model (the measurement model i.e. the relationship between the indicator and its construct) are specified. The result is residual variance of dependent variables.

\section{Result and Discussion}

\section{Results}

The results of this study were 90 respondents from village treasurers from 18 sub-districts in Magetan district. The AVE test for each construct/variable with the recommended rating must be greater than 0.50 . The following are the results of the AVE test for each variable of this study. The results of the Cronbach's Alpha and Composite Reliability testing for all constructs have a value above 0.70 , this indicates that all constructs have good reliability. 
Table 1 AVE

\begin{tabular}{ll}
\hline & AVE \\
\hline AKB & 0.552755 \\
GPM & 0.559525 \\
KMP & 0.568045 \\
BDR & 0.578538 \\
\hline
\end{tabular}

Source: PLS 2.0 output results (2021)

Table 2 Cronbach's Alpha and Composite Reliability

\begin{tabular}{lcc}
\hline & Cronbach's Alpha & Composite Reliability \\
\hline AKB & 0.863151 & 0.890202 \\
GPM & 0.918516 & 0.929847 \\
KMP & 0.836088 & 0.87453 \\
BDR & 0.892421 & 0.901147 \\
\hline
\end{tabular}

Source: PLS 2.0 output results (2021)

R-Square testing to measure each endogenous latent construct/dependent variable as the predictive power of the structural model. Changes in the R-Square value can be used to explain whether it has a substantive effect. R-Square value $0.67=$ strong, $0.33=$ moderate $/$ fair, and $0.19=$ weak Hair et al, (2011). The following are the results of the R-Square test.

Table 3 R-Square

\begin{tabular}{lc}
\hline & R Square \\
\hline AKB & 0.939523 \\
GPM & \\
KMP & \\
BDR & \\
\hline
\end{tabular}

Source: PLS 2.0 output results (2021)

The results of the R-Square test in table 3 showed that the dependent varibael value of 0.939523 diats value 0.67 in strong category. This shows that the larger the Rsquare number shows the larger the independent variable can explain the dependent variable so that the better the structural equation.

The hypothesis of this study can be seen from the path coefficients and Tstatistics. With this technique, researchers can assess the statistical significance of the research model by testing hypotheses for each relationship path. Hypothesis testing is based on T-calculated values $>1.65$ significance at $10 \%,>1.96$ significance at $5 \%$, and $>2.58$ significance at 1\% (Chin, 1998 and Hair et al, 2011 in Ghozali, 2014). The study used the significance of $>1.96$ at the level of $5 \%$. Here are the results of the Path Coefficients test on each hypothesis path. 
Table 4 Path Coefficients (Mean, STDEV, T-Values)

\begin{tabular}{lccccc}
\hline & $\begin{array}{c}\text { Original } \\
\text { Sample } \\
(\mathbf{O})\end{array}$ & $\begin{array}{c}\text { Sample } \\
\text { Mean } \\
(\mathbf{M})\end{array}$ & $\begin{array}{c}\text { Standard } \\
\text { Deviation } \\
(\text { STDEV) }\end{array}$ & $\begin{array}{c}\text { Standard } \\
\text { Error } \\
(\text { STERR) }\end{array}$ & $\begin{array}{c}\text { T Statistics } \\
(\mid \mathbf{O} / \text { STER } \\
\mathbf{R} \mid)\end{array}$ \\
\hline $\mathrm{BDR}$-> AKB & 0.442128 & 0.447968 & 0.061345 & 0.06135 & 7.207199 \\
$\mathrm{KMP}$-> AKB & 0.10589 & 0.107658 & 0.040601 & 0.0406 & 2.608179 \\
$\mathrm{BDR}$ * GPM -> AKB & 0.050924 & 0.007519 & 0.400705 & 0.400705 & 2.127085 \\
$\mathrm{KMP} *$ GPM -> AKB & 1.001118 & 0.917564 & 0.278801 & 0.278801 & 3.590801 \\
\hline
\end{tabular}

Source: PLS 2.0 output results (2021)

The results of the Path Coefficients test can be seen that the organizational culture towards accountability of village fund management (BDR > AKB) has a TStatistics value of 7.207199 with a path coefficient of 0.442128 this shows that the number has a significant effect because it is above 1.96 and the path coefficient is in a positive direction. Competence to accountability of village fund management (KMP > AKB) has a T-Statistical value of 2.608179 with a path coefficient of 0.10589 this shows that the number has a significant effect because it is above 1.96 and the path coefficient is in a positive direction. Competence moderated by leadership style has a significant positive effect on the accountability of village fund management (KMP * GPM > AKB) with a T-Statistics value of 2.127085 and a pathway coefficient of 0.050924 . Organizational culture moderated by Leadership Style has a significant positive effect on accountability of village fund management with a T-Statistic value of 3.590801 and a pathway coefficient of 1.001118 .

\section{Discussions}

The results of the data analysis showed that competence had a positive and significant effect on the accountability of village fund management. This shows that competence has an important role in implementing village fund management. Competence is the ability to perform work in accordance with standards and regulations. If competence is higher eat fund management the more accountable.

Organizational culture has a positive and positive influence on accountability for village fund management from data analysis. The results of this study show that organizational culture is a habit of carrying out the work in accordance with the rules that have been set. If the culture of village government organization is good (following the rules) then the management of village funds is accountable. And previously, if the organizational culture has a habit of carrying out activities that do not follow the rules that have been established, it will have an impact on the management of un accountable village funds.

Leadership style is able to realize the influence of competence on accountability of village fund management positively and significantly. This shows that leadership 
style is a way to influence his subordinates to do things that are cooled by the leader or village head. If the village head wants the village government officials who are competent to manage village funds properly, then accountability will be achieved. And conversely, if the village chief does not want the village government officials to do right, accountability is not achieved.

Leadership style is able to realize the influence of organizational culture on accountability of village fund management in a positive and significant manner. This shows that the leadership style of the village head is a determinant of the habits of the village government organization in carrying out its work. If the village head familiarizes the village government with the implementation of work in accordance with applicable norms then the management of village funds will be accountable. And conversely, the village head used the village government to do work not in accordance with existing norms, eating the management of village funds is not accountable.

\section{Conclusion}

The results of this study can be concluded that organizational culture and competence have a positive and significant effect on the accountability of village fund management. The leadership style is able to moderate the influence of organizational culture and competence and organizational culture on the accountability of village fund management significantly and positively. Accountable management of village funds requires village heads who are able to carry out leadership functions in accordance with established rules. So that the organizational culture in the village government has the habit of carrying out activities in accordance with predetermined standards and rules. In addition, the village head is also able to influence his subordinates to improve the competence of village government officials with various trainings and further studies so that the management of village funds is better and more accountable. The limitation of this research is that the respondents are only village treasurers in the Magetan district. For further research, it is possible to add respondents who can reach the Madiun residency and add new variables.

\section{References}

Ainsworth, M., Smith, N. and Millership, A. 2007. Managing Performance Managing People. Jakarta: PT. Bhuana Ilmu Populer.

Alimbudiono, Ria S., \& Fidelis A. A. (2004). Kesiapan Sumber Daya Manusia Sub Bagian Akuntansi Pemerintah Daerah "XYZ" dan Kaitannya Dengan Pert anggungjawaban Keuangan Daerah Kepada Masyarakat: Renungan Bagi Akuntan Pendidik. Jurnal Akuntansi dan Keuangan Sektor Publik. 5(2), 18-30. https:/ / scholar.google.com/scholar?cluster=17562830798266495573\&hl=en\&oi =scholarr 
Amertadewi, T., I., M. \& Dwirandra (2013. Pengaruh Partisipasi Anggaran terhadap Kinerja Manajerial dengan Gaya Kepemimpinan dan Locus of Control sebagai variabel moderasi. Jurnal Akuntansi Universitas Udayana. ISSN: 2302-8556.

Ainsworth M, Smith, M dan Millership. 2007. Managing Performance. Managing People. Terjemahan. Buana Ilmu Popular Jakarta. Anwas OM

Baba, Ali. 2018. Pengaruh Kompetensi, Komunikasi dan Budaya Organisasi terhadap Kinerja Karyawan PT. Semen Bosowa Maros. EKUITAS (Jurnal Ekonomi dan Keuangan).

524-540. https://ejournal.stiesia.ac.id/ekuitas/article/view/106

David, Fred R. (2004) Manajemen Strategi, Konsep. Edisi Ketujuh, Alih Bahasa Alexander Sindoro, Jakarta: Prehalindo.

Fitriyah, N. (2013). Pengaruh Kompetensi Sumber Daya Manusia Terhadap Kualitas Penyajian Mahayani. Prosocial Behavior Laporan Keuangan dan Implikasinya Terhadap Akuntabilitas Keuangan Pemerintah Daerah Kota Sukabumi. Tesis. Jakart a: Universit as Pendidikan Indonesia.

Ghozali, Imam, 2006, Structural Equation Modeling Metode Alternatif dengan Partial Least Square, Badan Penerbit Universitas Diponegoro, Semarang.

Ghozali, Imam. 2014. Structural Equation Modeling Metode Alternatif Dengan Partial Least Squares (PLS). Edisi 4. Badan Penerbit Universitas Diponegoro. Semarang.

Hair, J.F. Ringle, C.M \& Sarstedt, M. (2011) PLS-SEM: indeed a silver bullet. Journal of Marketing Theory and Practice, vol. 19, no. 2 (spring 2011), pp. 139-151. (C) 2011 M.E. Sharpe.

Hupe, P dan Hill, M. 2007. Street-Level Bureucracy and Public Accountability. Journal $\begin{array}{llll}\text { Public Administration, } & 85 & \text { (2), } & \text { 219-229. }\end{array}$ https:/ / research.brighton.ac.uk/en/publications/street-level-bureaucracyand-public-accountability

James L. et al. (1996). Organisasi: Perilaku, Struktur, Proses. Diterjemahkan oleh Ninuk Adriani. Jakarta: Binarupa Aksara.

Kartono, K. 2005. Kepemimpinan : Apakah Kepemimpinan Abnormal itu? Jakarta: PT. Raja Grafindo Persada.

Mada, S., Kalangi, L. \& Gamaliel H. (2017) Pengaruh Kompetensi Aparat Pengelola Dana Desa, Komitmen Organisasi Pemerintah Desa, dan Partisipasi Masyarakat terhadap Akuntabilitas Pengelolaan Dana Desa di Kabupaten Gorontalo. Jurnal Riset Akuntansi dan Auditing "Goodwill". 8 (2). 106-115. https:/ / ejournal.unsrat.ac.id/index.php/goodwill/article/view/17199

Mardiasmo. (2006). Pewujudan Transparansi dan Akuntabilitas Publik Melalui Akuntansi Sektor Publik: Suatu Sarana Good Governance. Journal. Akuntansi Pemerintahan, 2 (1). https://syukriy.wordpress.com/2010/01/12/pewujudantransparansi-dan-akuntabilitas-publik-melalui-akuntansi-sektor-publik-suatusarana-good-governance/ 
Novellno, A. (2019). ICW Sebut Korupsi Dana Desa Desa Kian Meningkat. CNN Indonesia. https://www.cnnindonesia.com/nasional/20191116150502-20448925/icw-sebut-korupsi-dana-desa-desa-kian-meningkat

Pahlawan, Wijayanti dan Suhendro (2020). Pengaruh Kompetensi Apatatur Desa, Sistem Pengendalian Internal, Pemanfaatan Teknologi Informasi dan Partisipasi Masyarakat terhadap Akuntabilitas Pengelolaan Dana Desa. Indonesia Accounting Journal, 2 (2), 162-172

Raharjo, T. Sjamsuddin, S. Hardjanto, I. (2013). Implementasi Kebijakan Alokasi Dana Desa (ADD) Tahun 2011 Di Desa Jembul dan Desa Sumengko Kecamatan Jatirejo Kabupaten Mojokerto. Jurnal Administrasi Publik, 16 (1), 32-40 https:/ / wacana.ub.ac.id/index.php/wacana/article/view/273

Ramadhan, A. (2019) Catatan ICW, Kasus Korupsi Dana Desa Terbanyak pada 2019. KOMPAS.com.

https:/ / nasional.kompas.com/read/2020/02/18/19084421/catatan-icw-kasus korupsi-dana-desa-terbanyak-muncul-pada-2019

Reni and Syamsir (2019) Pengaruh Budaya Organisasi terhadap Nagar dalam pengelolaan keuangan Nagara di Kabupaten Tanah Datar. Jurnal Administrasi $\begin{array}{lrrr}\text { Negara, } & 25 & \text { (1), }\end{array}$ http://journal.stialanmakassar.ac.id/index.php/jurnal_administrasi_negara/a rticle/view/539

Rivai, V. dan Mulyadi, D. 2013. Kepemimpinan dan Perilaku Organisasi. Jakarta: PT. Raja Grafindo Persada.

Robbins, S. P. 2006. Teori Organisasi: Struktur Desain dan Aplikasi. Ahli Bahasa: Yusuf Udaya. Jakarta: Arcan.

Robert. D. 1992. Pelayan Sebagai Pemimpin. Malang: Gandum Mas.

Santoso, E. B. 2016. Pengaruh Sistem Pengendalian Intern Pemerintah, Pemanfaatan Teknologi Informasi dan Kompetensi Sumber Daya Manusia Terhadap Akuntabilitas Keuangan Daerah (Studi Empiris pada Pemerintah Kabupaten Lampung Timur). Tesis. Bandar Lampung. Universitas Lampung.

Scott, C. (2002). Accountability in The Regulatory State. Journal of Law and Society, 27 (1), 38-60. https:/ / onlinelibrary.wiley.com/doi/abs/10.1111/1467-6478.00146

Sudarmanto. 2009. Kinerja dan Pengembangan Kompetensi SDM Teori, Dimensi dan Implementasi dalam Organisasi. Yogyakarta; Pustaka Pelajar.

Sudiarianti, N. M. (2013). Pengaruh Kompetensi Sumber Daya Manusia pada Penerapan Sistem Pengendalian Intern Pemerintah dan Standar Akuntansi Pemerintah serta Implikasinya pada Kualitas Laporan Keuangan Pemerintah Daerah, Tesis. Denpasar: Universitas Udayana.

Sukoco (2019). Akui Korupsi Dana Desa Selama 3 Tahun, Kades Magetan Dibui 2,5 Tahun.

KOMPAS.com https:/ / regional.kompas.com/read/2019/02/02/08341541/akui-korupsi-danadesa-selama-3-tahun-kades-di-magetan-dibui-25-tahun 
Tampubolon, Biatna. D. (2007). Analisis Faktor Gaya Kepemimpinan Dan Faktor Etos Kerja Terhadap Kinerja Pegawai Pada Organisasi Yang Telah Menerapkan SNI19-9001-2001. Jurnal Standardisasi. 9 (3), 106-115. https://js.bsn.go.id/index.php/standardisasi/article/view/684

Thomas. 2013. Pengelolaan Alokasi Dana Desa Dalam Upaya Meningkatkan Pembangunan Di Desa Sebawang Kecamat an Sesayap Kabupaten Tana Tuding. Journal Pemerintahan Integratif, 1 (1), 51-64. https://jurnal.untan.ac.id/index.php/JEDA2/article/view/28748

Trang, D,. S. (2013). Gaya Kepemimpinan dan Budaya Organisasi Pengaruhnya terhadapnya Kinerja Karyawan. Jurnal EMBA. 1 (3) 208-216.

Ubaidillah, M. and Arumsari, D. (2019) Pengaruh Tata Kelola terhadap Akuntabilitas Pengelolaan Dana Desa dengan Profesionalisme SDM dan Integritas sebagai Variabel Intervening. Journal of Islamic Finance and Accounting. 2 (1) 15-27.

Umaira dan Adnan. (2019) Pengaruh Partisipasi Masyarakat, Kompetensi Sumber daya Manuasia, dan Pengawasan terhadap Akuntabilitas Pengelolaan Dana Desa (Studi Kasus pada Kabupaten Aceh Barat Daya). Jurnal Ilmiah Mahasiswa Ekonomi Akuntansi (JIMEKA). 471-481

Umaira, S. \& Adnan (2019) Pengaruh Partisipasi Masyarakat, Kompetensi Sumber Daya Manusia, dan Pengawasan terhadap Akuntabilitas Pengelolaan Dana Desa (Studi Kasus pada Kabupatan Aceh Barat Daya. Jurnal Ilmiah Mahasiswa Ekonomi Akuntansi. 3 (4)

http://www.jim.unsyiah.ac.id/EKA/article/view/12580

Widiyanta, Herawati dan Atmadja (2017) Pengaruh Kompetensi Aparatur, Budaya Organisasi, Whistleblowing Dan Sistem Pengendalian Internal Terhadap Pencegahan Fraud Dalam Pengelolaan Dana Desa (Studi Empiris Pada Pemerintah Desa Di Kabupaten Buleleng). Jurnal Ilmiah Mahasiswa Akuntansi, 8 (2), 1-12.https:/ / ejournal.undiksha.ac.id/index.php/S1ak/article/view/1393 